\title{
Calcium intake in the first five days of life in the low birthweight infant
}

\author{
Effects of calcium supplements
}

\author{
M. MOYA AND E. DOMÉNECH \\ From the Department of Paediatrics, Hospital General y Clinico, Tenerife
}

SUMMARY Sixteen low birthweight infants were allocated to two groups. Both groups 1 and 2 received a formula with $\mathrm{Ca} / \mathrm{PO}_{4}$ ratio of $1 \cdot 21$. Group 2 infants received a supplement of $800 \mathrm{mg} / \mathrm{kg}$ per day of $\mathrm{Ca}$ and $\mathrm{Mg}$ lactate, and the daily $\mathrm{Ca}, \mathrm{Mg}$, and $\mathrm{PO}_{4}$ levels were measured. Calcium intakes (mg/kg per day) were, comparing groups 2 and 1: 82 v. 33 on the 1st day; 133 v. 45 on 2nd; 170 v. 56 on $3 \mathrm{rd} ; 224$ v. 72 on 4 th; 263 v. 88 on 5th. Magnesium intake (mg/kg per day) was 4.9 v. $3 \cdot 8$ on the 1 st day; $8 \cdot 3$ v. $5 \cdot 3$ on 2 nd $; 9 \cdot 8$ v. $6 \cdot 5$ on $3 \mathrm{rd} ; 15 \cdot 5$ v. $8 \cdot 3$ on 4 th; $16 \cdot 0$ v. $10 \cdot 0$ on 5th. Phosphate intake was similar in both groups. Mineral content of vomits and regurgitations showed more $\mathrm{Ca}$ than $\mathrm{P}$, with a ratio of 1:68. Comparing the two groups, in the supplemented infants, serum $\mathrm{Ca}$ rose from the $3 \mathrm{rd}$ day by an amount which was related to $\mathrm{Ca}$ intake: serum $\mathrm{Mg}$ was lower from the 4th day and was negatively correlated with $\mathrm{Ca}$ intake.

Early neonatal hypocalcaemia (ENH) is a clinical condition (Tsang and $\mathrm{Oh}, 1970)$ experienced by most preterm infants in the first 24-48 hours of life, which can give rise to serious complications-such as heart failure (Troughton and Singh, 1972) and other cardiac disorders (Colletti et al., 1974; Doménech et al., 1976), and to difficulties in management (Volpe, 1973; Weiss et al., 1975), or, at a later stage, to mental disturbances (Forfar, 1974), or dental defects (Purvis et al., 1973; Stimmler et al., 1973).

Pathogenesis remains obscure. Among factors which may be involved are hypoparathyroidism (Anast et al., 1972; David and Anast, 1974), disorders of, or lack of, vitamin D (Hillman and Haddad, 1974), and hypercalcitonism (Hillman et al., 1977), but there is no evidence of their direct implication in the production of this disorder of homeostasis. Some perinatal events may predispose to ENH (Bergman, 1974; Tsang et al., 1976). Alimentary factors are important: e.g. calcium/ phosphate ratios and the quality and quantity of fat (Southgate et al., 1969; Barltrop and Oppé, 1970, 1973).

Balance experiments allow the rate of mineral gain by the neonate to be measured, but for obvious reasons it is necessary to start after the 5th day of

Received 8 November 1977 life (Widdowson, 1965; Day et al., 1975). Because ENH occurs before this time, and in view of the placental $\mathrm{Ca}$ transfer rate, it seems important to quantify the total intake of $\mathrm{Ca}, \mathrm{P}$, and $\mathrm{Mg}$ in this early period of life.

The purpose of the investigation was to find out whether supplements of $\mathrm{Ca}$ and $\mathrm{Mg}$ to the diets of low birthweight infants would increase their serum $\mathrm{Ca}$.

\section{Patients and methods}

Sixteen neonates of low birthweight were studied. They were between 34 and 38 weeks' gestation, determined by the mothers' last menstrual period and the scoring method of Dubowitz, and between 1420 and $2470 \mathrm{~g}$. They were assigned to two groups. Mean birthweight, gestation, height, and Apgar scores were not significantly different in the two groups.

Group 1 (9 infants). These received a formula with lactose and normal total fat content, but partially substituted by vegetable fat. The mineral content is shown in the Table. $\mathrm{Ca}: \mathrm{P}$ ratio measured by us, is near the lower limit given by the Committee on Nutrition of the American Academy of Pediatrics (1976). 
Table Mineral content of the basic formula

\begin{tabular}{lcc}
\hline $\begin{array}{l}\text { Content } \\
(\mathrm{mg} / 100 \mathrm{ml})\end{array}$ & According to label & $\begin{array}{l}\text { Results of analysis* } \\
(n=45)\end{array}$ \\
\hline $\mathrm{Ca}$ & 49 & $55 \cdot 32 \pm 0.16$ \\
$\mathrm{Mg}$ & $4 \cdot 76$ & $6 \cdot 32 \pm 0.04$ \\
$\mathrm{PO}_{4}$ & $39 \cdot 20$ & $45 \cdot 55 \pm 0.08$ \\
$\mathrm{Ca} / \mathrm{PO}_{4}$ ratio & 1.25 & $1 \cdot 21 \pm 0.002$ \\
\hline
\end{tabular}

*Mean \pm SEM.

Group 2 (7 infants). These received the same formula but supplemented with $800 \mathrm{mg} / \mathrm{kg}$ per day Ca lactate containing $13.5 \mathrm{mg} \mathrm{Ca}$ and $0.45 \mathrm{mg} \mathrm{Mg}$ element in each $100 \mathrm{mg}$ of the salt, divided in 7 doses and mixed with each feed.

In both groups feeding was started between the first 6 and 12 hours of life and with a schedule rising from $50 \mathrm{kcal} / \mathrm{kg}(0 \cdot 21 \mathrm{MJ} / \mathrm{kg})$ on the 1st day to 120 $\mathrm{kcal} / \mathrm{kg}(0.50 \mathrm{MJ} / \mathrm{kg})$ on the 5 th. Energy intake was calculated from manufacturer's data.

The concentrations of $\mathrm{Ca}, \mathrm{Mg}$, and $\mathrm{P}$ in the diet were measured by taking an aliquot of each feed. They were dried and ashed at $450^{\circ} \mathrm{C}$ and then dissolved in $\mathrm{HCl}$. $\mathrm{Ca}$ and $\mathrm{Mg}$ were measured by atomic absorption spectrophotometer, and $\mathrm{P}$ by the method of Fiske and Subbarow. Vomits and regurgitations were collected on ashless filter paper (Whatman no. 541), processed in the same way, and subtracted from intake.

Blood samples were obtained daily before the first feed in the morning.

Informed parental consent was obtained. All figures appearing in the text are expressed as mean \pm SEM. Comparison of means was made by Student's $t$ test.

\section{Results}

Because results were not significantly different in appropriate-for-gestation age (AGA) and small-forgestational age (SGA) infants, comparisons were made only between groups 1 and 2 .

Mineral intake. In group $1 \mathrm{Ca}$ intake was $33 \pm 3$ $\mathrm{mg} / \mathrm{kg}$ per day on $1 \mathrm{st}$ day, rising to $88 \pm 2 \mathrm{mg} / \mathrm{kg}$ per day on day 5 . In group $2 \mathrm{Ca}$ intake was $82 \pm 17$ $\mathrm{mg} / \mathrm{kg}$ per day on 1 st day, rising to $263 \pm 19 \mathrm{mg} / \mathrm{kg}$ per day on day 5 .

There was a parallel rise in $P$ intake in both groups and no significant differences between them. On the 5th day $P$ intake was $73 \pm 2$ in group 1 infants and $82 \pm 5$ in group 2 .

After the 1st day there were differences in $\mathbf{M g}$ intakes between the two groups. Throughout the 5 days, $\mathrm{Mg}$ intake per day $(3.8 \pm 0.3$ to $16.0 \pm 1.0$ $\mathrm{mg} / \mathrm{kg}$ per day) was within the wide range of the
Mg supplied by most milk formulae, although the $\mathrm{Mg}$ intake of group 2 was in the upper part of the range.

Plasma minerals concentration. The Figure shows that serum total $\mathrm{Ca}$ began to rise significantly from the 3rd day with a rising trend in group 2, reaching $9.25 \pm 0.19$ v. $7.77 \pm 0.35 \mathrm{mg} / 100 \mathrm{ml}$ on the 5 th day. Levels of significance are shown. Two days after the supplementation ended, total serum $\mathrm{Ca}$ in group 2 was $8.70 \pm 0.26 \mathrm{mg} / 100 \mathrm{ml}$. At the 7 th day of life, for group 1, this figure was $8.25 \pm 0.35$ $\mathrm{mg} / 100 \mathrm{ml}$.

Serum $P$ (Figure) showed little change in either group, with an initial and final mean of 5.6 and 5.5 $\mathrm{mg} / 100 \mathrm{ml}$ in group 1 ; and 4.52 and 5.27 in group 2 . Serum Mg showed higher values in group 1 from the 4th day. On the 1st day the lower level of group 1 was owing to the presence of two babies with hypomagnesaemia (0.9 and $1.1 \mathrm{mg} / 100 \mathrm{ml})$. Apart from these, all values were above the accepted lower limit for adults $(1.4 \mathrm{mg} / 100 \mathrm{ml})$.

Correlations. Correlations were sought between all variables analysed, including weight and gestational age. None was significant, except calcaemia and $\mathrm{Ca}$ intake $(\mathrm{r}=0.55 ; \mathrm{P}<0.01)$, and magnesaemia and $\mathrm{Mg}$ intake $(\mathrm{r}=0.54 ; \mathrm{P}<0.01)$, the first day values having been excluded because of their known higher values. A negative correlation between serum $\mathrm{Mg}$ level and $\mathrm{Ca}$ intake $(\mathrm{r}=-0.81 ; \mathrm{P}<0.001)$ was noted in group 2 .

\section{Discussion}

The incidence of ENH even in babies born of mothers not at risk for this complication raises the point that $\mathrm{Ca}$ is among a number of elements which should normally accumulate in the last trimester of pregnancy. If the placental pump ceases there are two mechanisms available for maintaining $\mathrm{Ca}$ homeostasis-via the external nutrients supply or from bone resorption. Three considerations are pertinent to neonatal $\mathrm{Ca}$ regulation: (1) placental supply, (2) bone Ca reservoir, and (3) alimentary supply. According to Shaw $(1973,1976)$ the placental transfer at term is about $150 \mathrm{mg} / \mathrm{kg}$ per day, and this is because an active transport mechanism (Armstrong et al., 1970) maintains a higher cord blood Ca level, $10.36 \pm 0.11 \mathrm{mg} / 100 \mathrm{ml}$, than that of venous maternal blood, $9.58 \pm 0.10(\mathrm{n}=12 ; \mathrm{P}<0.001)$ (Moya and Doménech, 1976). A large proportion of the plasma $\mathrm{Ca}$ is ionised (Delivoria-Papadopoulos et al., 1967) and these high levels in the fetus stimulate calcitonin and inhibit parathormone secretion producing conditions favourable to the 


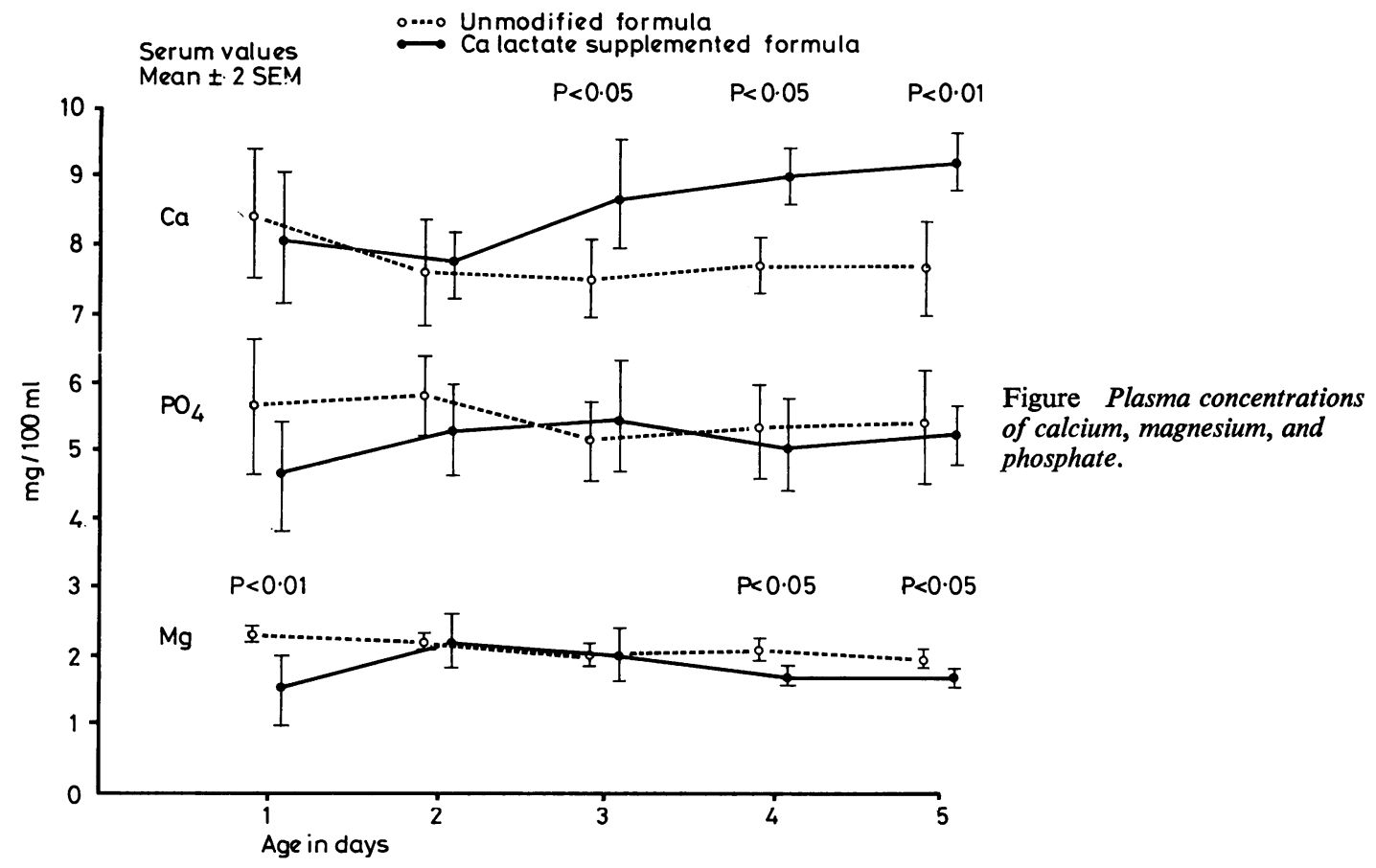

accelerating $\mathrm{Ca}$ accumulation during the last trimester of pregnancy (Pitkin, 1975).

After delivery the placental $\mathrm{Ca}$ flow is abruptly interrupted and the fetal situation is maintained by means of some degree of parathyroid inertia and some hypercalcitonism (Bergman et al., 1974; David and Anast, 1974; Hillman et al., 1977); $\mathrm{Ca}$ homeostasis should then depend on osseous mobilisation or on exogenous supply. Bone contribution is limited in the neonatal period, because $\mathrm{Ca}$ reserves are considerably smaller in the newborn, $0.71 \%$ of body weight (Stearns, 1939), than at older ages, $1.6 \%$ of body weight (Walser, 1961). These reserves may be reduced by a restriction of dietary $\mathrm{Ca}$ by the pregnant mother, at least in the rat (Moya and Vento, 1976), although there is no exact parallel with humans, since in rats blood $\mathrm{Ca}$ levels do not fall despite the low $\mathrm{Ca}$ content of the diet. Local food habits, with poor $\mathrm{Ca}$ supply or with natural chelants for this cation may aggravate this situation in the pregnant woman through maternal hypocalcaemia (Watney et al., 1971). Moreover the skeleton of a baby born prematurely, in contrast to what occurs in the same period of intrauterine life, fails to mineralise significantly within the first 28 days of extrauterine life (McIntosh et al., 1977).

Concerning alimentary supply we have seen how with a rather generous caloric schedule and a conventional formula, the actual $\mathrm{Ca}$ intake in the first 5 days was $32,45,55,71$, and $87 \mathrm{mg} / \mathrm{kg}$, and with an appropriate $\mathrm{Ca} / \mathrm{PO}_{4}$ ratio. In a previous series of infants (Moya and Doménech, 1976), we observed a negative $\mathrm{Ca}$ and $\mathrm{Mg}$ balance in one baby because of a tendency to regurgitate. In the first day the loss was $4 \mathrm{mg} / \mathrm{kg} \mathrm{Ca}$ and $1.4 \mathrm{mg} / \mathrm{kg} \mathrm{Mg}$. In the present study the mineral content of vomits and regurgitations was measured. In group 1 the total $\mathrm{Ca}$ regurgitated was higher than $\mathrm{P}$, thus the daily $\mathrm{Ca} / \mathrm{P}$ ratio in this regurgitated material was greater than in the feed formula, 1.68, 1.66, 1.61, $1.97,1 \cdot 34$. In group 2 this ratio was higher, because the $P$ regurgitated was kept at the same level as in group 1-2.90, 1.85, 2.51, 1.95, 3.05. Despite its addition, the $\mathrm{Mg}$ content in the regurgitated material of this group was not as high. The number of vomits and regurgitations did not differ significantly in either group.

This study was designed to examine the effectiveness of supplementing $\mathrm{Ca}$ intake to prevent early neonatal hypocalcaemia. In group 2 only one baby suffered from hypocalcaemia and on the first day. By contrast, in group 1, 5 out of the 9 infants had a serum $\mathrm{Ca}<7 \mathrm{mg} / 100 \mathrm{ml}$ at least in one sample, needing oral or parenteral $\mathrm{Ca}$ administration. Serum $\mathrm{Mg}$ reflected the extra $\mathrm{Ca}$ intake, with lower levels at the end of the study, and we found 3 cases of symptomless hypomagnesaemia $(<1.4 \mathrm{mg} / 100 \mathrm{ml})$ all of which subsided spontaneously. Competition of 
divalent cations in the absorbing process carried out by the enterocyte may explain this-a hypothesis in keeping with the negative correlation found between serum $\mathrm{Mg}$ level and $\mathrm{Ca}$ intake.

We have shown that on a conventional formula the infants in this study had received $87 \mathrm{mg} / \mathrm{kg}$ per day of $\mathrm{Ca}$ by day 5 . As a fetus of 36 weeks' gestation may receive placentally $150 \mathrm{mg} / \mathrm{kg}$ per day, the conventional formula would appear to provide too little $\mathrm{Ca}$. When infants received supplements of $\mathrm{Ca}$ lactate, a $\mathrm{Ca}$ intake of $150 \mathrm{mg} / \mathrm{kg}$ per day was achieved between the 2nd and 3rd day of life, and these infants exhibited significantly higher levels of serum $\mathrm{Ca}$ on days 4 and 5 . As there was no change in the plasma $P$, these data suggest that a useful amount of the additional $\mathrm{Ca}$ was absorbed.

\section{References}

Anast, C. S., Mohs, J. M., Kaplan, S. L., and Burns, T. W. (1972). Evidence for parathyroid failure in magnesium deficiency. Science, 177, 606-608.

Armstrong, W. D., Singer, L., and Makowski, E. L. (1970). Placental transfer of fluoride and calcium. American Journal of Obstetrics and Gynecology, 107, 432-434.

Barltrop, D., and Oppé, T. E. (1970). Dietary factors in neonatal calcium homoeostasis. Lancet, 2, 1333-1335.

Barltrop, D., and Oppé, T. E. (1973). Calcium and absorption by low birthweight infants from a calcium-supplemented milk formula. Archives of Disease in Childhood, 48, 580-582.

Bergman, L. (1974). Studies on early neonatal hypocalcemia. Acta paediatrica Scandinavica, Supplement 248, 1-25.

Bergman, L., Kjellmer, I., and Selstam, U. (1974). Calcitonin and parathyroid hormone-relation to early neonatal hypocalcemia in infants of diabetic mothers. Biology of the Neonate, 24, 151-160.

Colletti, R. B., Pan, M. W., Smith, E. W. P., and Genel, M. (1974). Detection of hypocalcemia in susceptible neonates. New England Journal of Medicine, 290, 931-935.

Committee on Nutrition of the American Academy of Pediatrics (1976). Commentary on breast-feeding and infant formulas, including proposed standards for formulas. Pediatrics, 57, 278-285.

David, L., and Anast, C. (1974). Calcium metabolism in newborn infants. Journal of Clinical Investigation, 54, 287-296.

Day, G. M., Chane, G. W., Radde, I. C., Reilly, B. J., Park, E., and Sheepers, J. (1975). Growth and mineral metabolism in very low birthweight infants. II. Effects of calcium supplementation on growth and divalent cations. Pediatric Research, 9, 568-575.

Delivoria-Papadopoulos, M., Battaglia, F. C., Bruns, D. P., and Meschia, G. (1967). Total protein-bound and ultrafilterable calcium in maternal and fetal plasmas. American Journal of Physiology, 213, 363-366.

Doménech, E., Moya, M., Bosch, V., Paredes, C., and Marco, V. (1976). Valor diagnóstico del alargamiento del intervalo Q-T en la hipocalcemia neonatal. Medicina española, 75, 367-373.

Forfar, J. O. (1974). Biochemical fits in the newborn. Proceedings of the Rnyal Society of Medicine, 67, 375-377.

Hillman, L. S., and Haddad, J. G. (1974). Human perinatal vitamin D metabolism. I. Hydroxyvitamin D in maternal and cord blood. Journal of Pediatrics, 84, 742-749.

Hillman, L. S., Rojanasathit, S., Slatopolsky, E., and
Haddad, J. G. (1977). Serial measurements of serum calcium, magnesium, parathyroid hormone, calcitonin, and 25-hydroxy-vitamin $\mathrm{D}$ in premature and term infants during the first week of life. Pediatric Research, 11, 739-744.

McIntosh, N., Shaw, J. C. L., and Taghizadeh, A. (1977). Accumulation of nitrogen and collagen in the femur of the human foetus, and the effects of premature birth (abstract). Pediatric Research, 11, 1023.

Moya, M., and Doménech, E. (1976). Hipocalcemias neonatales. XIV Congreso Español de Pediatria, 27-30 October 1976, Barcelona (pp. 29-36 conference proceedings).

Moya, M., and Vento, M. (1976). Effects of low calcium diet over pregnant rats' and offsprings' calcium contents (abstract). Pediatric Research, 10, 890.

Pitkin, R. M. (1975). Calcium metabolism in pregnancy: a review. American Journal of Obstetrics and Gynecology, 121, 724-737.

Purvis, R. J., MacKay, G. S., Cockburn, F., Barrie, W. J. M., Wilkinson, E. M., Belton, N. R., and Forfar, J. O. (1973). Enamel hypoplasia of teeth associated with neonatal tetany: manifestation of maternal vitamin $\mathrm{D}$ deficiency. Lancet, 2, 811-814.

Shaw, J. C. L. (1973). Parenteral nutrition in the management of sick low birthweight infants. Pediatric Clinics of North America, 20, 333-358.

Shaw, J. C. L. (1976). Evidence for defective skeletal mineralization in low birthweight infants: the absorption of calcium and fat. Pediatrics, 57, 16-25.

Southgate, D. A. T., Widdowson, E. M., Smits, B. J., Cooke, W. T., Walker, C. H. N., and Mathers, N. P. (1969). Absorption and excretion of calcium and fat by young infants. Lancet, 1, 487-489.

Stearns, G. (1939). The mineral metabolism of normal infants. Physiological Reviews, 19, 415-438.

Stimmler, L., Snodgrass, G. J. A. I., and Jaffe, E. (1973). Dental defects associated with neonatal symptomatic hypocalcaemia. Archives of Disease in Childhood, 48, 217-220.

Troughton, T. K., and Singh, S. P. (1972). Heart failure and neonatal hypocalcaemia. British Medical Journal, 4, 76-79.

Tsang, R. C., and Oh, W. (1970). Neonatal hypocalcemia in low birthweight infants. Pediatrics, 45, 773-781.

Tsang, R. C., Strub, R., Brown, D. R., Steichen, J., Hartman, C., and Chen, I. W. (1976). Hypomagnesemia in infants of diabetic mothers: perinatal studies. Journal of Pediatrics, 89, 115-119.

Volpe, J. (1973). Neonatal seizures. New England Journal of Medicine, 289, 413-416.

Walser, M. (1961). Ion association. VI. Associations between calcium, magnesium, inorganic phosphate, citrate, and protein in normal human plasma. Journal of Clinical Investigation, 40, 723-730.

Watney, P. J. H., Chance, G. W., Scott, P., and Thompson, J. H. (1971). Maternal factors in neonatal hypocalcemia, a study in three ethnic groups. British Medical Journal, 2, 432-436.

Weiss, Y., Ackerman, C., and Shmilovitz, L. (1975). Localised necrosis of the scalp in neonates due to calcium gluconate infusions: a cautionary note. Pediatrics, 56, 1084-1086.

Widdowson, E. M. (1965). Absorption and excretion of fat, nitrogen, and minerals from 'filled' milks by babies one week old. Lancet, 2, 1099-1105.

Correspondence to Professor M. Moya, Department of Paediatrics, Hospital General y Clínico, Faculty of Medicine, La Laguna, Tenerife, Spain. 